\title{
Tales from Fragments: A Review of Indian Human Skeletal Studies
}

\author{
Veena Mushrif-Tripathy $\mathbb{D}^{1}$ \\ ${ }^{1}$ Department of AIHC and Archaeology, Deccan College Post Graduate and Research Institute Pune, India 411006
}

\begin{abstract}
India provides large number of skeletal data from the pre- and protohistoric levels covering a time span of almost 10,000 years. Major skeletal collection comes from the cultural phases ranging from the Mesolithic, Harappan, Neolithic, Chalcolithic and Iron Age levels. After the Early Historic phase cremation became the most common method for disposing the dead. Though the relevant documentation is far less than complete, recovery of human burials has been reported from more than 300 sites (Mushrif-Tripathy et al. 2016) and a conservative estimate would lead to imagine approximately 2000 human skeletons. The human skeletal analysis started around 1950s and initial focus of the study was to understand the racial classification of the skulls and to prove the Indo-Aryan invasion theory. Later from 1980s multidisplinary approach including socio-cultural anthropology, growth and nutrition and medical anthropology were considered. The recent development includes the use of new scientific methods like isotope, aDNA, DXA scans, and Scanning Electron Microscope studies etc. are consider to understand ancient inhabitants of Indian Sub-continent.
\end{abstract}

Keywords : South Asia, India, Human Skeletons, Archaeology, Aryan issue

\section{INTRODUCTION}

India is a part of Asia continent and has located in the strategic position in route from East to West. The arrival of European colonial powers in late $18^{\text {th }}$ century gave rise to Indian cultural studies. Their curiosity to know about the land and its inhabitants provided the impetus to understand various features of India. This resulted into establishment of Geological, Botanical and Trigonometric surveys. Further these developments led the foundation of the Asiatic Society in Kolkata by William Jones in 1788, which contributed to the foundation of Archaeological Survey of In-

The author(s) agree to abide by the good publication practice guideline for medical journals.

The author(s) declare that there are no conflicts of interest.

Received: May 9, 2019; Revised: June 4, 2019; Accepted: June 14, 2019

Correspondence to: Veena Mushrif-Tripathy (Department of AIHC and Archaeology, Deccan College Post Graduate and Research Institute, Pune, India 411006)

E-mail: vmushrif@gmail.com dia in 1861. If we examine the various developmental stages of the subject, we notice that India was at the receiving end of theories that were developed mainly in Europe and were verified, testified and implemented on the subcontinent. Documenting developmental stages of archaeological anthropology is an enormous task therefore the framework of this paper is based on a number of earlier review papers [1-8].

\section{MATERIALS AND METHODS}

The oldest evidence of human skeletal remains is from the site of Hathnora dated back to 0.15 MYA-40,000YBP probably belonging to Homo erectus. There are one partial crania and 14 post-cranial bones from the site [9-11]. Table number 1 describes the general chronology of the cultural sequence where human remains are found in archaeological 
Table 1. Time brackets of different cultures with human skeletal findings from India

\begin{tabular}{|c|c|c|}
\hline Culture & Main Regions & Time brackets \\
\hline Middle Palaeolithic Homo erectus? & Narmada, Madhya Pradesh & 0.15 MYA-40,000YBP \\
\hline Mesolithic (hunting gathering populations) & Gangetic duob & 8000 B.C. \\
\hline Harappan Culture (Urban dwellers and long distance trade) & North west part of India, Gujarat & $3500-1500 \mathrm{BC}$ \\
\hline Neolithic-Chalcolithic (Early agro-pastoral communities) & Maharashtra, Karnataka, Kashmir & 2000-700 BC \\
\hline Later Mesolithic (hunter-gathers and co-existence with chalcolithic culture) & Gujarat & $2000 \mathrm{BC}$ \\
\hline $\begin{array}{l}\text { Megalithic (mainly pastoral communities with co-existence with chalcolithic } \\
\text { culture) }\end{array}$ & Vidharbha, Southern states & $1000 \mathrm{BC}-2^{\text {nd }} \mathrm{c}$ AD \\
\hline Early Historic, Medieval and Pre Modern (from diverse subsistence pattern) & At various places & $2^{\text {nd }} \mathrm{c} \mathrm{AD}-17^{\text {th }} \mathrm{c} \mathrm{AD}$ \\
\hline
\end{tabular}

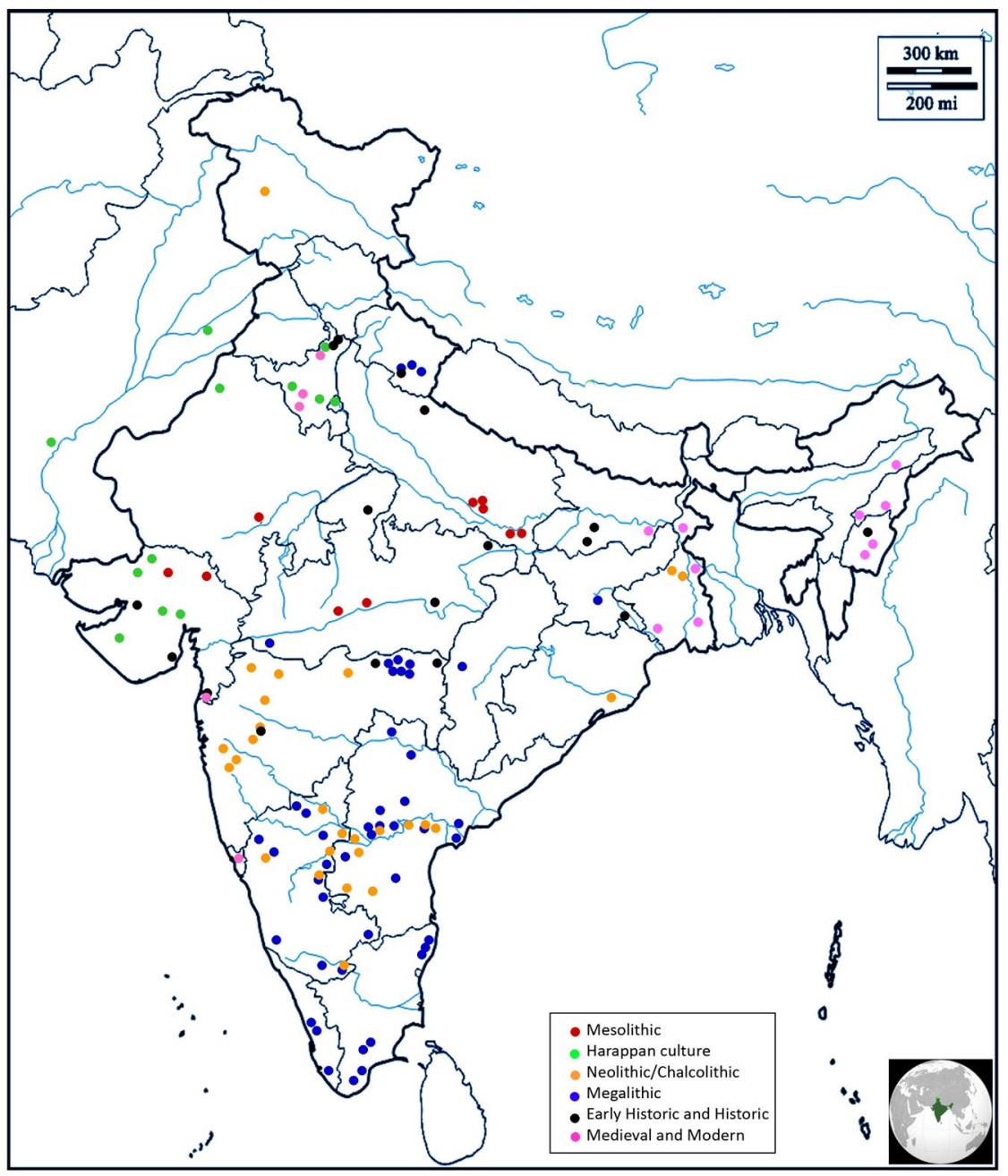

Fig. 1. Map of India: Approximate locations of the sites belonging to different cultures.

excavations and the Figure 1 shows the approximate locations of sites and the distribution. Though there are around 300 sites which provide human remains, not more than 50, has studied using modern technologies [12].

As the archaeological anthropological literature started in 1800s, there are large numbers of papers published at various journals. The more 'scientific' analysis began around 1950s and monographs were published based on those studies. For this review article, data represented here is based on the reports published at different places. Along with that, other literature related to specific topic or site is referred. The citations are given at appropriate places. 


\section{RESULTS}

The discussion is divided into main stages on the subject development. Author is very much concerned and aware of the using particular terminologies like 'race' or 'types to races'. The terms are being used for the readers understanding and not validation. In early 1940s, around II World War, anthropology discipline was justifying the 'racial' studies in every part of the world, the same approach was forced on the skeletal collections from India. This stage cannot be ignored and is important to know to understand the present status. This background will also vital to develop strategies for future.

\section{In search of 'racial' identities}

Before the independence of India in 1947 and the creation of the Anthropological Survey of India in 1946 there were many discoveries of human remains from different parts and belonging to various past cultural entities. These discoveries were made and studied by a range of British officials, geologists and enthusiastic amateur explorers/ excavators such as Tucker (1846), Taylor (1853), Blanford (1864), Boswell (1872), Aderson (1883) [1,3]. The main focus of these studies was to establish the ethnic identity of the remains, their relationships with contemporary populations and their racial categorization. The cranium was the focal point of discussion and post-cranial bones were collected but only used for age, sex and the stature estimations.

This approach lasted until the late 1970s despite the impact on archaeology of events such as the discovery of the Bronze Age city of Harappa in the 1920s. This was not only a very important discovery in Indian archaeology but also a major event from the perspective of the development of physical anthropology as a discipline in India. Numerous discoveries followed which provided physical anthropologists with many skeletal assemblages for population comparisons. This offered an ideal environment to evaluate theories of migration, diffusions and invasions [13,14]. A 'foreign' population was held responsible or given credit for any new trend or material artefact (mainly during the Protohistoric period), rather than ascribing the development to local evolution. At times foreign invaders were held responsible for the extinction of a culture and for that reason it was necessity to 'classify' the population 'racially'
[6]. British and Indian anthropologists followed the guidelines of the Biometrika School. Prior to World War II, the majority of Indian biological anthropologists who studied abroad received training in Germany. The anthropometric basis for population divisions was not only seen in the colonial mind-set but it was also prominently reflected in the Census of India report in 1931, which was responsible for establishing the model of how the native populations of British India were classified $[15,16]$. Thus anthropometry became a very important part of anthropological research in India; cranial shape differences (in form of dolichocrania or mesocrania) were understood in terms of 'mixing of blood' as well as establishing biological affinities between ancient and living populations on the basis of comparative measurements and morphology.

\section{Foundation being led}

This scenario started to change in the 1970s, when processes like adaptation were considered as one of the major factors for population differences. At the same time, concepts like migration, diffusion and 'mixing of the blood' came under criticism. The skeletal data were no longer regarded as isolated evidence but they were seen in the context of culture. A strong trend persisted though in the use of anthropometric interpretations of population affinities. Many skeletal assemblages were studied at two prime places during this period; one the Anthropological Survey of India and other Deccan College Post-Graduate and Research Institute, Pune.

This was the time when the collaborations with foreign anthropologis helped in creating a niche for human skeletal studies in Indian archaeology. Under the guidance of Prof. Iravati Karve, an anthropologist at Deccan College, studies of human remains started around 1945. She strove to understand biological variation in extant populations. At the same time the archaeology department excavated a few sites (e.g. Chandoli, Nevasa, Langhnaj, Mahujhari, Baghor) which yielded skeletal remains. The team work along with K.A.R. Kennedy of Cornell University, USA, Deccan College and S. Ehrhardt, a German anthropologist skeletal assemblages were studied [17]. Kennedy encouraged his students to study skeletal remains while at the same time he also trained his Indian colleagues in different methodologies. Dr. Karve encouraged one of her students, Dr. K. C. Malhotra, to conduct human skeletal studies and this result- 
ed in number of publications on human skeletal remains from Nevasa, Chandoli, T. Narsipur, Piklihal [18-21].

\section{Breakthrough of 1980s}

During the early 1980s, skeletal studies gained a new importance within the field of Indian archaeology. Concepts like adaptation, growth and nutrition and their effects on the skeleton were better understood and these criteria were used for understanding ancient populations. Models from social anthropology and ethnographic studies on health helped to understand the changes in human body due to diet, diseases, infant mortality, life expectancy, etc. were incorporated. This 'bio-cultural' approach become vital in skeletal analysis.

Earlier studies were focused only on the human skeletal remains of adults resulting in small samples for understanding the nature of populations. During the 1980s, subadult individuals were incorporated in the analysis as well as fragmented bones were also considered. This resulted in a drastic increase in numbers of individuals available to represent the extant population. The questions of infant mortality rates, age of weaning, the role of infections and malnutrition were prioritized. At the same time, the publication of the edited book 'Palaeopathology at the Origins of Agriculture' [22] had a major impact on skeletal biologists all over the world.

Deccan College played a prominent role in the development of the subject [23]. This is only university in India where the post of Lecturer was created in the field of skeletal anthropology at an archaeology department. A lab was established for the same purpose in 1980. During this time, the research goals of the Anthropological Survey of India shifted from skeletal analysis to projects like 'People of India' which has the biggest human skeletal repository of ancient and modern populations from different regions. As a result of these developments, anthropological research for the last three decades was primarily remained confined to the Deccan College where ancient skeletal assemblages are kept and studied. In India, the subject was developed by Prof. S. R. Walimbe (Head of the Anthropology Department (Retd.), Savitribai Phule Pune University). He was associated with Deccan College around three decades and founded anthropology laboratory. He has studied more than 40 skeletal assemblages from different sites [24-27] and also with other collaborators [28-31]. This remains the only working laboratory in India dedicated to work on skeletal anthropology. The present author has worked on many skeletal remains from India and is trying to implement new technologies to improve the subject at the same department independently or with other colleague [32-43]. Allahabad University also invited foreign collaborations [6] and understood the importance of human skeletal remains.

The collaborations directly or indirectly helped the growth of the subject in India. As mentioned earlier, K. A. R. Kennedy was among the first external scholars to engage with the sub-continent, followed by his student J. Lukacs (University of Oregon, Oregon). They established new palaeodemographic trends in skeletal and dental research. Dr. Diana Hawkey, another of the Kennedy students, worked extensively on the dentition of Indian samples [44]. Lukacs's students B. Hemphill (California State University, Bakersfield) and G. Robbin-Schug (Appalachian University, Appalachian) also worked on Indian material.

\section{Steps towards future}

Continuous development in sciences has its impact on the osteoarchaeology as well. It is very much seen during $21^{\text {st }}$ century. A few unsuccessful attempts were made for extracting Ancient DNA, as outlined in a paper published in the American Journal of Physical Anthropology [45]. In the paper authors concluded that 'there is insufficient DNA surviving in Indian specimens for analysis from tropical environments' and they also suggested that samples should be collected from sites in non-tropical environments and/ or from cave sites [45]. This situation has slightly changed during in recent years with collaboration between Deccan College and Centre for Cellular and Molecular Biology, Hyderabad (CCMB). The ancient DNA laboratory facility has been created in the CCMB which have given opportunities to experiment with ancient DNA analysis. The first extraction of aDNA published in 2014 from human bone remains excavated from St. Augustine convent, Goa, dated to from medieval period [46] and another Medieval site Sanjan from Gujarat [47] has given some hope to try more samples. In both cases the sites are not very old in chronology. Studies undertaken at CCMB on the Roopkund human remains, a glacial lake in Uttarakand, is also successful in isolating ancient DNA [48]. The paper based on Roopkund will be published soon.

The fruitful attempt was made on dental samples from 
Harappan site of Farmana [49] for isotope analysis. In this paper authors tried stable isotopes, strontium and lead. The results were interesting showing early age migrations to Farmana. Currently Indian samples are being tested through isotope analysis to understand the ancient migrations.

Recent approaches have become more scientific in nature but at the same time the disciplines seek many explanations from sociological and cultural angles. This change in research strategies is reflected in two major ways. One is understanding the role of 'continuous' metric and 'discrete' non-metric (morphological) traits, their relevance in population movements and assessment of micro-evolutionary changes, particularly those seen in at the transition to agriculture; and secondly, in the field of palaeopathology where cultural aspects have become more important and instead of 'what is it?', the quest now is for 'why and how is it there?'.

Palaeopathology has become a significant aspect in human skeletal studies as it reflects physiological stress and health during adaptation to different subsistence strategies, economies and environments. The presence of maxillary sinusitis, vertebral arthritis, clavicular bone changes, squatting facets on the tibia, dental abrasions and wear patterns are some of the common indicators of habitual activities. India still has some pockets where people are living using primitive technologies. These ethnographic parallels also hint at the health hazards of the bygone population. Unhygienic conditions, repetitive pregnancies and low nutritious diets in present societies gives an indication of past vulnerabilities in terms of malnutrition, high infection rates, and increases in child mortality rates.

Presence of maxillary sinusitis in archaeological populations from protohistoric (1500 B.C.) and medieval (around $17^{\text {th }}$ century) India is very interesting and it is very good example to understand it from socio-economic perspective. Considering the ethnographic aspects, the study reveals that inflammation possibly caused by inhaling polluted air for a long duration or because of dental disease. Also, apart from pollution in domestic zones, external pollution because of vocation is also discussed in this study using relevant ethnographic parallels [50].

The interpretative approach in palaeopathology is used while understanding the biological process at the end of the Indus civilization. It is noticed that the prevalence of infection and infectious disease increased through time. Corresponding mortuary differences suggest that socially and economically marginalized communities were most vulnerable in the context of climate uncertainty at Harappa. Observations of the intersection between climate change and social processes in proto-historic cities offered valuable lessons about vulnerability, insecurity, and the longterm consequences of short-term strategies for coping with climate change [41].

Other inferences were drawn from the trauma analysis seen on the Harappan skeletal remains. While describing the Harappan population in 'A peaceful realm? Trauma and social differentiation at Harappa' [40], mentions that the prevalence and patterning of cranial injuries, combined with striking differences in mortuary treatment and demography among the three burial areas indicate interpersonal violence in Harappan society was structured along lines of gender and community membership. The results contradict the dehumanizing, unrealistic myth of the Indus Civilization as an exceptionally peaceful prehistoric urban civilization. The interpretations seem to be amplified to some extent, as these observations are based on not very large sample. If we assume that Harappans lived in large cities for more than 2000 years at that particular area, the skeletal remains are not more than 250 individuals. Out of that only comparatively few have indication of trauma related to violence. So it is quite difficult to have projections regarding the societal unrest during that time. The use of structural violence seems to be over rated during the interpretation.

There are also attempts to incorporate the details from ancient Indian texts to understand bygone societies. These texts contain information about mortuary practices, general life of the people and also pathology. Texts like Atharvave$d a$ (around 1200 B.C.) discuss various health problems and associated remedies, from medico-magical perspectives. Sushruta samhita $\left(5^{\text {th }}\right.$ century A.D. $)$ deals with surgeries and Ayurveda is very popular even today for its healing capacity.

\section{DISCUSSION}

\section{In the of search of 'Aryans' and Indian anthropology}

While debunking the 'Aryan invasion theory', Walimbe [6] discussed how the concept of an Indo-Aryan group of people and their 'invasion' has played a prominent role in explaining the cultural history of the Indian sub-continent. 


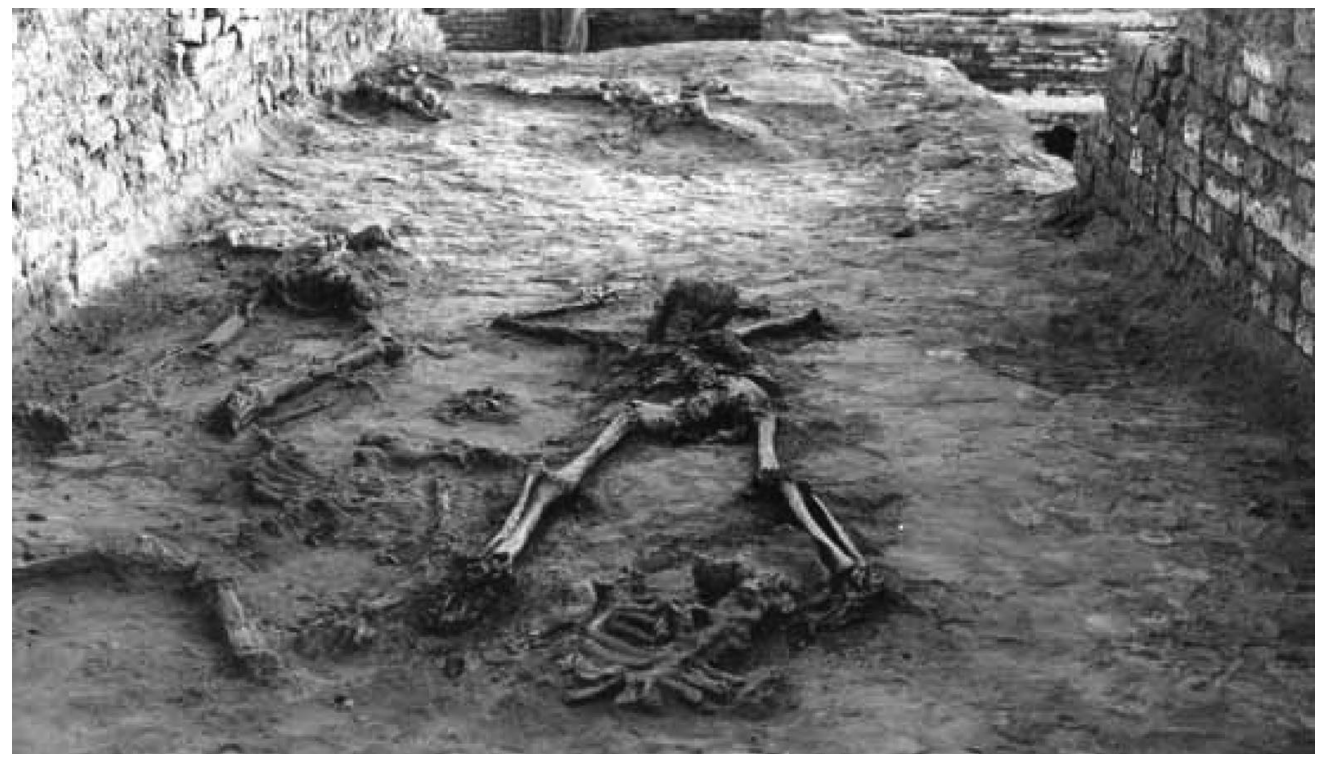

Fig. 2. Disoriented skeletal remains from Mohenjodaro (from published data).

This concept can be traced back as early as the $19^{\text {th }}$ century, when Max Mueller [51], thrilled by the complexity of Indian culture, used the word "Aryan Race" and thus emerged an imaginary creature "Aryan Man". Borrowing from earlier ideas about Aryans in Europe, he propounded the theory that the group invaded the Indian subcontinent around 1500 $\mathrm{BCE}$, later settled in India and that they were the people who destroyed the big cities at Harappa and Mohenjo-daro.

The discovery of Harappa and Mohenjo-daro in 1920s was a very crucial moment from an anthropological point of view. These are huge cities located on the north-west of India that provide early evidence of urbanization. Other than these sites, Chanu daro, Kalibangan and Lothal show uniformity in their architectural and pottery assemblages. Together have been named as Harappan civilization or Indus civilization which flourished around $4000 \mathrm{BCE}$ to 1500 BCE. Around 1500 BCE there is archaeological evidence indicating the sudden decline of this civilization. This was a big question to address. At Mohenjo-daro the excavators encountered disarticulated skeletons on roads and in other parts of the city rather than in cemeteries (Fig. 2). Many skeletons were either disarticulated or incomplete. Marshall [52] attributed plague, famine and 'sudden' events as causes of death. Mackey [53] suggested that these individuals had been slain by raiders while attempting to escape from the city during a military attack. Several disassociated causes, including the enigmatic ab- sence of a formal mortuary area at the site, were taken as supporting evidence for this "massacre" and this idea was immediately seized upon as awful proof of the invasion of the sub-continent by the 'Aryans'. Wheeler [54], while accusing the Aryans of destroying the cities of the Harappan civilization and for the "massacre" at Mohenjo-daro, cited the Vedic texts describing that the 'Aryans' were brave, efficient and dreadful warriors who knew the bow-and-arrow; that horses were used to pull their chariots; and that they were protected by armour and shields [7].

As a result, skeletal analysis of these remains focused on answering questions related to identity including: who were these people and where did they come from? Craniometric data were used to classify and justify the 'foreign element' within the population. The first concise and well-documented report on the skeletal material from Harappa and Mohejo-daro was by Sewell and Guha [55]. Guha [56,57]) recognized four racial groups while describing the Mohejo-daro population, which he labelled as Mediterranean, Proto-Australoid, Alpine and Mongoloid. This classification became the basis for future studies involving the analysis of skeletal assemblages from different sites. In 1962, Gupta, Dutta and Basu [58] restudied the skeletal findings from Cemetery R-37, Area-G, Area-AB and Cemetery-H at Harappa and classified them into similar categories. According to this latter study, the presence of long-headed (dolichocranial) people was noted in all areas whereas the 
round-headed or brachycranial population was only seen in Area-G, concluding that this was a new type.

There have been more recent attempts to understand differences seen in the Harappan population. Many physical anthropologists have studied Harappan crania [59-61] came to the conclusion that there is not much evidence to prove the presence of a foreign element in Harappa. Kennedy [61] mentioned that "our multivariate approach does not define the biological identity of an ancient Aryan population, but it does indicate that the Indus Valley and Gandhara peoples shared a number of craniometric, odontometric and discrete traits that point to a high degree of biological affinity", thus completely denying the theory of 'Aryan invasion'. With new advances in studies and re-evaluation, no significant phenotypic differences in the population have been found and even though the Harappan skeletal assemblages come from different deposits, they appear to belong to one homogeneous group. As these assemblages come from Harappan cities, the variation in size and shape can be explained with migrations and immigrations of different population from surrounding areas. As these cities had large trade networks with other parts of the world, it is possible that many merchants or traders may have travelled to these locations.

The so-called invasion is also called into question from a palaeopathological point of view. A number of studies considered evidence of trauma in the disarticulated skeletal remains from Mohenjo-daro. Dales [62,63] noted that the skeletal collection he studied and that examined by Marshall and Mackey did not represent a single archaeological time frame. The temporal and cultural contexts of these remains are uncertain and it may not be sound to consider them evidence relating to a single tragic episode. Dales [62] also pointed out that on purely chronological grounds no definite correlation between the end of Indus civilization and the "Aryan invasion" can be established. The Harappan skeletal collection was restudied by Kennedy $[64,65]$ in the light of the new methodological approaches in the field of forensic anthropology and palaeopathology. He offered a very critical judgement of earlier narratives. He stated that "when present, marks of injury are quite specific in their appearance, both microscopic and macroscopic analyses revealing tell-tale features which are not to be confused with abrasions or other marks of erosional and post-mortem origin.....To be sure, individuals victimized by trauma may not bear the marks of their assailant or his weapons on their skeletal tissue (as with cases of drowning, strangulation, poisoning, cardiac arrest due to fright, etc.); but in cases of genocide (like military engagements, mass executions, ritual sacrifices) where multiple victims are involved it is usual for some individuals of a group to reveal marks of traumatic stress on their bones and teeth" [64]. Death by an axe or sword may not be registered on the bone if the wound is superficial and if only soft tissues are injured. But it is reasonable to expect actual wound-marks in case of unceremonious slaughter, which are not present in Mohenjo-daro specimens.

The proposition of a traumatic end of Harappan culture (Mohenjo-daro in particular) is based essentially on archaeological evidence of the disorderly disposal of the dead rather than on skeletal evidence of trauma. In this case the problem of interpreting the disarray of skeletons becomes more complicated. This haphazard mode of disposal of the dead might have had some social implications rather than being solely related to violent events. Anthropology or archaeology has no conclusive answer to this puzzle at present. It may be mentioned that some scholars believe that the Mohenjo-daro individuals exhibit a unique pattern of regional phenotypic variability with striking differences that set them apart from skeletal series at other Harappan sites. It has been claimed that the skeletons in question may belong to a post-Harappan period and share no direct biological affinity with the population of the mature Harappan phase [66].

To strengthen the 'no Aryan Invasion' hypothesis, data from human population genetics generated in recent years show that there is no material evidence for any large scale migrations into India over the period of 4500 to $800 \mathrm{BCE}$. On the basis of the presence of sub lineages of $\mathrm{U} 2$ frequencies (U2e and U2i), Basu [67] argue that Aryan speakers possibly came into India in small bands over a long period of time, as opposed to in a single wave of migration.

Indian anthropology has been gone through lot of changes since its beginning. With technological advances new trends are incorporated in analysis on human skeletal remains. Some of the researches are about the documentation of new pathologies which were not done earlier, and trying to interpret those using sociological models. The characterisation of palaeo-diets through chemical analysis and the recording of dental morphological traits are also included in these analyses. At the same time more and more skeletal assemblages are being analysed from these scientific perspectives. For the stature estimation for the skeletal remains 
from India, DEXA scan was used. DEXA stands for dual energy $\mathrm{X}$-ray absorptiometry - a mouthful of a term that actually tells a lot about this procedure, in which two X-ray beams are aimed at the bones. It has provided formulas for the stature estimation using Indian population [68]. One more attempt is made to estimate body mass and composition from proximal femur dimensions using dual energy X-ray absorptiometry [69]. The present generation of Indian physical anthropologists seeks collaborations with social anthropologists, archaeologists, geneticists, linguists, and medical professionals in order to further the development of the subject.

\section{REFERENCES}

1. Murthy MLK. Twenty five years of research on human osteological remains from prehistoric sites in India. Bul of the Deccan College Res Inst. 1974; 34:116-31.

2. Tavares A. Skeletal biology in India- A historiographical study. Bull Deccan College PG and RI. 1993; 53:357-70.

3. Kennedy KAR. God-apes and fossil men: Paleoanthropology of South Asia. Ann Arbor: The University of Michigan Press; 2003a.

4. Kennedy KAR. The uninvited skeleton at the archaeological table: The crisis of paleoanthropology in South Asia in the twenty-first century. Asian Perspectives; 2003b.

5. Kennedy KAR. Archaeological and anthropological research in South Asia: Developments over the past 50 Years. Man Environ. 2005; 30:36-41.

6. Walimbe SR. Human skeletal studies: Changing trends in theoretical and methodological perspectives. Indian J Anthropol Soc. 2011a; 46: 305-41.

7. Walimbe SR. The Harappan civilization and human skeletal biology: A fresh look. In: Chakrabarti DK, editor. A new history and culture of the Indian people, Vol.II, Vivekananda International Foundation; 2011b.

8. Mushrif-Tripathy V. Human Skeletal Studies in India: A Review. In: O'Donnabhain B, Lozada C, María C, editors. Archaeological Human Remains: Global Perspectives. Springer International Publishing; 2014 . p. 139-54.

9. Sonakia A. Narmada Man. Am J Phys Anthropol. 1991; 86: 475-96.

10. Sonakia A. Antiquity of the Narmada Homo erectus, the Early Man of India. Curr Sci. 1998; 75:391-3.

11. Sankhyan AR. Hominin Fossil Remains from the Narmada Valley. In: Robbins Schug G, Walimbe SR, editors. A Companion to South Asia in the Past. Hoboken, NJ: John Wiley and Sons, Inc; 2016. p. 72-85.
12. Mushrif-Tripathy V, Chakraborty KS, Lahiri S. Where Are They Now? The Human Skeletal Remains from India. In: Robbins Schug G, Walimbe SR, editors. A Companion to South Asia in the Past. Hoboken, NJ: John Wiley and Sons, Inc; 2016. p. 496-533.

13. Sewell RBS, Guha BS. Reports on the bones excavated at Nal. Mem. Archaeol. Surv. India. 1929; 35:56-86.

14. Guha BS, Basu PC. Report on the human remains excavated at Mohenjodaro in 1928-29. In: Mackay JH, editor. Further Excavations at Mohenjodaro. New Dehli: Government of India; 1938. p. 613-38.

15. Guha BS. The Racial Elements in Indian Populations. Oxford University Press. London. 1944.

16. Risley HH. Chapter. In: Crooke W, editor. The People of India (Memorial edition). Calcutta: Thacker, Spink; 1908. p. 278.

17. Ehrhardt S, Kennedy KAR. Excavation at Langhnaj: 19441963: Part III: The Human Remains. Deccan College Build. Centen. Silver Jubilee Ser. 27. Pune: Deccan College; 1965.

18. Kennedy KAR, Malhotra KC. Human skeletal remains from Chalcolithic and Indo-Roman levels from Nevasa: An anthropometric and comparative analysis. Pune: Deccan College Research Institute; 1966.

19. Malhotra KC. Human skeletal remains from Chandoli. In: Deo SB, Ansari ZD, editors. Chalcolithic Chandoli Deccan College Build. Centen. Silver Jubilee Ser. 39; 1965. p. 6980.

20. Malhotra KC. Further observations on human skeletal remains from neolithic Piklihal. Anthropologist. 1967; 14:99111.

21. Malhotra KC. Report on the human skeleton from the burial. In: Sheshadri M editor. Report on the Excavation at T. Narsipur. Bangalore: Government of India; 1971. p. 79104.

22. Cohen MN, Armelagos JG, editors. Palaeopathology at the origins of agriculture. Orlando: Academic Press; 1984.

23. Walimbe SR. Biological anthropology at the Deccan College: Prof. Irawati Karve and beyond. In: Walimbe SR, Jogalekar PP, Basa KK, editors. Anthropology for archaeology: Proceeding of the Professor Irawati Karve birth centenary seminar, Pune: Deccan College; 2007a. p. 49-60.

24. Walimbe SR. Paleodemography of protohistoric Daimabad. In: Sali SA, editor. Daimabad 1976-79. New Dehli: Archaeological Survey of India; 1986. p. 641-740.

25. Walimbe SR. Human skeletal remains. In: Dhavalikar MK, Shinde VS, Atre S, editors. Excavations at Kaothe. Pune: Deccan College Research Institute; 1990. p. 111-231.

26. Walimbe SR. A report on adult human skeleton recovered from Neolithic Ieej (A.P.). Bulletin A.P. State Dept. of Archaeology and Museums; 1994. 
27. Walimbe SR. Bio-cultural adaptations in cranial morphology among the early farming Chalcolithic populations of the Deccan Plateau. In: Bhasin MK, Malik SL, editors. Contemporary studies in human ecology: Human factor, resource management and development. Delhi: Indian Society for Human Ecology; 1998. p. 25-40.

28. Lukacs JR, Walimbe SR. Paleodemography at Inamgaon: An Early Farming Village in Western India. In Lukacs JR Editor, The People of South Asia: The Biological Anthropology of India, Pakistan and Nepal. New York: Plenum Press; 1984. p. 105-32.

29. Lukacs JR, Walimbe SR. Excavations at Inamgaon: Vol II: The Physical Anthropology of Human Skeletal Remains: Part i: An Osteographic Analysis. Pune: Deccan College Research Institute; 1986.

30. Walimbe SR, Selvakumar V. Anthropological investigations on an Iron Age adult male skeleton from S.Pappinayakkanpatti, Madurai district, Tamil Nadu. J Hum Evol. 1998; 9:19-34.

31. Walimbe SR, Paddayya K. Human skeletal remains from the neolithic Ashmound site at Budihal, Gulbarga district, Karnataka. Bull Deccan College PG and RI. 1999; 58-59: 11-47.

32. Mushrif V, Walimbe SR. Human skeletal remains from Chalcolithic Nevasa: Osteobiographic analysis. Oxford: BAR International Series. 147; 2006.

33. Mushrif-Tripathy V, Tosi TJ, Vasa D, Walimbe SR. Human skeletal remains from Jotsoma. Kolkata: Centre for Archaeological Studies and Training, Eastern India; 2008.

34. Mushrif-Tripathy V, Sankhyan AR, Rao VR. A short note on Palaeopathological Observations on Human skeletal remains from Sarai Nahar Rai at Anthropological Survey of India, Kolkata. Man Environ. XXXIV. 2009: 66-76.

35. Mushrif-Tripathy V, Rajan K, Walimbe SR. Megalithic builders of South India: Archaeo-anthropological investigations on human skeletal remains from Kodumanal. Bhopal: Indira Gandhi Rashtriya Manav Sangrahalaya; Pune: Centre for Ancient Human Skeletal Studies; and New Dehli: Aryan Books International; 2011.

36. Mushrif-Tripathy V, Walimbe SR. Human skeletal remains from the medieval site of Sanjan: Osteobiographic analysis. Oxford: BAR international series. 2353; 2012.

37. Robbins G, Mushrif V, Misra VN, Mohanty RK, Shinde VS. Biographies of the skeleton: Palaeopathological conditions at Balathal. Man Environ. 2006; 31: 50-65.

38. Robbins G, Mushrif V, Misra VN, Mohanty RK, Shinde VS. Human skeletal remains from Balathal: A full report and inventory. Man Environ. 2007; 22:1-25.

39. Robbins G, Mushrif-Tripathy V, Misra VN, Mohanty RK, Shinde VS, Gray K, et al. Ancient skeletal evidence for leprosy in India (2000 B.C.). PLoS ONE. 2009; 4:e5669. doi:10.1371/journal.pone.0005669.

40. Robbins Schug G, Gray K, Mushrif-Tripathy V, Sankhyan AR. A peaceful realm? Trauma and social differentiation at Harappa. Int J Paleopathol. 2012; 2:136-47.

41. Robbins Schug G, Blevins KE, Cox B, Gray K, MushrifTripathy V. Infection, Disease, and Biosocial Processes at the End of the Indus Civilization. PLoS ONE. 2013; 8: e84814. doi:10.1371/journal.pone.0084814.

42. Jonnalagadda M, Ozarkar S, Mushrif-Tripathy V. Population affinities of Parsis in the Indian subcontinent. Int $\mathbf{J}$ Osteoarchaeol. 2011; 21:103-10.

43. Mushrif-Tripathy V, Shinde VS. Human Skeletal Assemblage from the Harappan Site of Farmana: A Bio-archaeological Analysis. New Delhi: Kaveri Books; 2019.

44. Hawkey DE. The peopling of South Asia: Evidence for affinities and microevolution of prehistoric populations from India/Sri Lanka. Spolia Zeylanica. 2002; 39:1-300.

45. Kumar SS, Nasidze I, Walimbe SR, Stoneking M. Discouraging prospects for ancient DNA from India. Am J Phys Anthropol. 2000; 113:129-33.

46. Rai N, Nizamuddin T, Singh M, Chaubey G, Jha N, Singh A, et al. Relic excavated in western India is probably of Georgian Queen Ketevan. Mitochondrion. 2014; 14:1-6. DOI: 14. 10.1016/j.mito.2013.12.002.

47. Chaubey G, Qasim A, Rai N, Prakash S, Mushrif-Tripathy V, Mezzavilla M, et al. Like sugar in milk: Reconstructing the genetic history of the Parsi population. Genome Biol. 2017; 18:110. DOI: 10.1186/s13059-017-1244-9.

48. Walimbe SR. DNA studies: Scope and prospects in Indian anthropology. In: Walimbe SR, Jogalekar PP, Basa KK, editors. Anthropology for archaeology: Proceeding of the Professor Irawati Karve birth centenary seminar, Pune: Deccan College; 2007b. p. 207-15.

49. Valentine B, Kamenov GD, Kenoyer JM, Shinde V, Mushrif-Tripathy V, Otarola-Castillo E, et al. Evidence for Patterns of Selective Urban Migration in the Greater Indus Valley (2600-1900 BC): A Lead and Strontium Isotope Mortuary Analysis. PLoS ONE. 2015; 10:e0123103. doi:10. 1371/journal.pone.0123103.

50. Mushrif-Tripathy V. Maxillary Sinusitis from India: A Bio-cultural Approach. in Korean J Phys Anthropol. 2014; 27:11-28.

51. Mueller M. Biographies of Words and the Home of the Aryas. London: Longmans, Green and Company; 1887.

52. Marshall J. Mohenjo-daro and the Indus Civilization. London: Probsthain; 1931.

53. Mackay EJH. Editor. Further Excavations at Mohenjo-daro. New Delhi: Government of India; 1938.

54. Wheeler REM. The Indus Civilization. 3rd Ed. Cambridge: 
Cambridge University Press; 1968.

55. Sewell RBS, Guha BS. Human Remains. In: Mohenjodaro and the Indus Civilization. In Marshall J, Editor, Being an Official Account of Archaeological Excavations Carried Out by the Govt. of India Between the years 1922-1927. Vol. II. London: Arthur Prosbsthain; 1931. p. 599-642.

56. Guha BS. The racial affinities of the people of India. Census of India 1931. 1935; 1:III-A:2-22.

57. Guha BS. Racial elements in the indian population. Oxford Pamphlets on Indian Affairs, No.22. London: Oxford University Press; 1944.

58. Gupta PC, Dutta PC, Basu A. Human Skeletal Remains from Harappa. Calcutta: Anthropological Survey of India; 1962.

59. Hemphill BE, Christensen AF, Mustafakulo SI. Trade or travel: An assessment of interpopulational dynamics among Bronze Age Indo-Iranian populations. In Allchin R, B Allchin editors. South Asian Archaeology 1995, Vol. 2. Oxford and New Dehli: IBH; 1997. p. 855-71.

60. Hemphill BE, Lukacs JR, Kennedy KAR. Biological adaptations and affinities of Bronze Age Harappans. In: Meadow RH, editor. Harappan excavation 1986-1990: A multidisciplinary approach to third millennium urbanism. Madison: Prehistory Press; 1991.p. 137-82.

61. Kennedy KAR. Have Aryans been identified in the prehistoric skeletal record from South Asia? Biological anthropology and concepts of ancient races. In: Erdosy G, Editor. The Indo-Aryans of ancient South Asia: Language, materi- al culture and ethnicity. Berlin: Walter de Gruyter; 1995. p. 32-66.

62. Dales GF. The mythical massacre at Mohenjodaro. Expedition. 1964; 6:37-43.

63. Dales GF. New Iinvestigations at Mohenjodarao. Archaeology. 1965; 18:145-50.

64. Kennedy KAR. Trauma and disease in the ancient Harappans: Recent assessments of the skeletal record. In: Lal BB, Gupta SP, Editors. Frontiers of the Indus Civilization. New Delhi: Books and Books; 1984. p. 425-36.

65. Kennedy KAR. Identification of sacrificial and massacre victims in archaeological sites: The skeletal evidence. Man Environ. 1994; 19:247-51.

66. Gadgil M, Thapar R. Human ecology in India: Some historical perspectives. Iterdiscipl Sci Rev. 1990; 15: 209-23.

67. Basu AN, Mukherjee SR, Sengupta S, Banerjee S, Chakraborty M, Dey B, et al. Ethnic India: A genomic view with special reference to peopling and structure. Genome Res. 2003; 2277-90.

68. Pomeroy E, Mushrif-Tripathy V, Wells JCK, Kulkarni B, Kinra S, Stock JT. Stature estimation equations for South Asian skeletons based on DXA scans of contemporary adults. Am J Phys. Anthropol. 2018; 167:20-31.

69. Pomeroy E, Mushrif-Tripathy V, Kulkarni B, Kinra S, Stock JT, Cole TJ, et al. Estimating body mass and composition from proximal femur dimensions using dual energy x-ray absorptiometry. Arch and Anth Sci. 2019; 11:2167-79. 